\title{
THE RISE OF SCHOOL-SUPPORTING NONPROFITS ${ }^{1}$
}

\author{
Ashlyn Aiko Nelson ${ }^{2} \quad$ Beth Gazley $^{3}$
}

This Draft: October 31, 2013

WORK IN PROGRESS: DO NOT COPY OR CITE WITHOUT AUTHORS' PERMISSION

Contact: bgazley@indiana.edu

\footnotetext{
${ }^{1}$ The authors thank the University of Texas' RGK Center for Philanthropy and Community Service and the Association for Research on Nonprofit Organization and Voluntary Action (ARNOVA) for financial support awarded via the RGK Center-ARNOVA Presidents Award for 2012. The authors also thank David Warren, Ed Gerrish, Thomas Sugimoto, Mir Usman Ali, Quentin Ball, Lynn Nguyen, and Megan Welch for excellent research assistance.

${ }^{2}$ Associate Professor, School of Public and Environmental Affairs, Indiana University - Bloomington, 1315 E. Tenth St., Office 410D, Bloomington, IN 47405, Tel: 812855 5971, Email: ashlyn@indiana.edu.

${ }_{3}^{3}$ Associate Professor, School of Public and Environmental Affairs, Indiana University - Bloomington, $1315 \mathrm{E}$. Tenth St., Office 410C, Bloomington, IN 47405, Tel: 812855 5971, Email: bgazley@indiana.edu.
} 


\title{
THE RISE OF SCHOOL-SUPPORTING NONPROFITS
}

\begin{abstract}
This paper examines voluntary contributions to public education via charitable school foundations, booster clubs and PTAs/PTOs as an alternative to local revenues generated via the property tax. We employ panel data on school-supporting charities with national coverage from 1995 to 2010, which we geocode and match to school districts. We first document the meteoric rise of school-supporting nonprofits during this panel, and then estimate a series of regression models including both reduced-form and fixed effects specifications to examine the distributional consequences of voluntary distributions. We find that districts with higher perpupil expenditures and higher enrollments are more likely to have one or more operating schoolsupporting charities, but that the level of per-pupil voluntary contributions declines with student enrollment. Higher-poverty school districts are less likely to be served by a school-supporting nonprofit and receive significantly lower voluntary contributions on a per-pupil basis. Finally, impressive recent growth in the number and financial size of these school supporting charities since 1995 has not offset reductions in state aid. Moreover, we do not find sufficient evidence to conclude that voluntary contributions change the distribution of funding across school districts and undo school finance equalization.
\end{abstract}

\section{INTRODUCTION AND RESEARCH QUESTIONS}

The recent fiscal crisis triggered major changes in the funding of K-12 public education. State tax receipts—which account for between 40 and 50 percent of revenues flowing to public schools - have declined by 12 percent in real terms since the start of the Great Recession in 2008 and constitute the sharpest decline on record (McNichol, Oliff and Johnson 2012). The 2009 American Recovery and Reinvestment Act temporarily offset these reductions in state aid by allocating $\$ 50$ billion in federal stimulus to public schools, but such infusions of federal funding are unlikely to continue in light of the current fiscal and political climate (Reschovsky 2013). Johnson and Leachman (2013) find that five years following the start of the Great Recession, state tax receipts remain five percent lower in inflation-adjusted terms than at the start. If federal and state aid to public education continues to decline, local government revenues will play an 
increasingly important role in offsetting these reductions and responding to pressures for increased levels of K-12 funding.

Property taxes currently generate over 80 percent of local own-source revenues for public schools (National Center for Education Statistics 2013; Reschovsky 2013). However, local governments often are unable to increase the level of property tax revenues flowing to local public schools due to state-level policies including property tax limitations, school finance equalization measures, and categorical funding requirements mandating the allocation of local revenues. These restrictions contribute to government failure, in which the level of public education spending in many school districts is lower than what many households are willing to pay. To increase school spending to desired levels, local governments often must rely on alternatives to the property tax such as sales taxes or voluntary contributions.

This paper examines voluntary contributions to public education as an alternative to local revenues generated via the property tax. We employ panel data on charitable contributions to public school districts to answer the following research questions:

1. How have voluntary contributions to public schools changed from 1995 through 2010 ?

2. What are the distributional consequences of voluntary contributions to public schools? We address this research question by modeling both the probability that a school district receives revenues from a school-supporting 501(c)(3) charity as well as the level of perpupil voluntary contributions as a function of school district characteristics.

3. To what extent do voluntary contributions offset reductions in state aid to public schools? We address this research question by modeling per-pupil voluntary contributions as a function of changes in state aid contributions and other school district characteristics. 
4. Is the recent rise in voluntary contributions sufficiently substantial to change the distribution of funding across school districts and to undo school finance equalization?

The remainder of the paper is organized as follows. In Section 2, we position our paper within the prior literature and the current policy context. Section 3 describes our data sources. Sections 4, 5, 6 and 7 address research questions 1-4 above, and Section 8 concludes.

\section{REVIEW OF THE LITERATURE}

\section{Voluntary Contributions to Public Services}

The topic of voluntary contributions to public services is well-explored. Brunner and Sonstelie (2003) provide an excellent review of several economic models of voluntary contributions. To summarize, these models include the "pure altruism" model in which an individual's voluntary contributions reflect the purely altruistic motivation to improve the provision of public goods (see Olson and Zeckhauser 1996; Warr 1983; Roberts 1984; and Bergstrom, Blume and Varian 1986) and joint-product models in which voluntary contributions produce both public goods and private goods benefiting the benefactor, such as "warm glow" and prestige (see Cornes and Sandler 1984; Andreoni 1988; Andreoni 1989; Andreoni 1990; Ledyard 1995; Sugden 1982;

Steinberg 1987; Glazer and Konrad 1996; and Harbaugh 1998). Brunner and Sonstelie (2003) empirically test and find evidence for their own model of partial cooperation in which some households free-ride off the voluntary contributions of others, and increases in voluntary contributions do not keep pace with proportional increases in the beneficiary base (i.e., the elasticity of donations with respect to the number of beneficiaries is less than one). 
During economic recessions, voluntary contributions may arise to address government failure to provide the desired level of public services. Even in the best of times, demand heterogeneity is natural, and devolving the choice of public services to the median voter's preference (or, in the case of school finance equalization, to state Supreme Court decisions) leaves some citizens unsatisfied. Because they are fairly easy to form in the U.S., nonprofit organizations provide a ready vehicle for collective action wherein communities can increase spending to desired levels (Lecy and Van Slyke 2013; Matsunaga and Yamauchi 2004; Salamon 1987; Young 1999). Voluntary contributions aimed at addressing government failure may be motivated via any of economic models described above.

The overlapping fields of public and nonprofit management explain the voluntary sector's participation in public service provision primarily through the lens of co-production. The study of co-production or citizen co-provision of public services began in the 1980s, during another recessionary era (see Brudney 1987, Parks et al. 1981, and Warren 1987). Traditionally, coproduction theory characterizes the citizen provision of public services as an activity in which citizens serve as both users and agents of service provision (Brudney and England 1983; Whitaker 1980; Parks et al. 1981). Historically, such activity has been explained via theories of government failure and cross-sectoral interdependence, which create the conditions for active government encouragement of charitable activity. Examples can also be seen in the philanthropic institutions that support many public libraries, parks, and emergency services. The discussion has been renewed in recent years (e.g., Brandsen and Karré 2011; Jetté and Vaillancourt 2011; Mizrahi 2011). For example, Lecy and Van Slyke (2013) and Matsunaga and Yamauchi (2004) examine how and where 501(c)(3) charitable entities form, and what relationship they have with the characteristics of their host jurisdictions. Cohen (2012) and 
O'Toole and Meier (2004) examine the impact of co-production on revenue streams and tax policy, and Paarlberg and Gen (2009) examine whether disparities in community philanthropic resources result in public service inequities. Several studies in public and nonprofit management question whether voluntary contributions form a sufficient and sustainable solution to government failure. Irwin and Carr (2005) find that voluntary contributions are a "minor and highly variable source of revenue" and "an ill-suited replacement for broad-based tax revenue" (p. 33). Similarly, Lecy and Van Slyke (2013) argue that revenues from philanthropic sources do constitute a stable source of funding for public institutions: "foundations can be fickle patrons as they may prefer to support new organizations, new programs, and themes that evolve over time and within a community" (p. 206).

\section{Voluntary Contributions to Public Schools}

Hansen (2008) lists a broad range of nongovernmental organizations - both nonprofit and forprofit — providing revenues to schools: "school-based organizations (parent associations, alumni associations, booster clubs), school foundations, local education funds, community foundations, local businesses, independent foundations, and corporations" (p. 315). Research on voluntary contributions to public schools primarily focuses on nonprofits classified as "charities" under Section 501(c)(3) of the tax code, sometimes referred to in the school context as education support organizations, or ESOs (e.g., Lampkin and Stern 2003). Referred to in this paper using the vernacular term "nonprofit", these school-supporting charitable organizations include Parent Teacher Associations (PTAs), Parent Teacher Organizations (PTOs), alumni associations, booster clubs, school foundations, and local endowments which operate at the local school or district level and form the most prevalent examples of supplementary philanthropic activity in

\footnotetext{
${ }^{4}$ Zimmer, Krop and Brewer (2003) use slightly different categorizations to characterize the voluntary contributions of nongovernmental organizations to California public schools.
} 
public education (Hansen 2008). These nonprofits obtain voluntary contributions via membership dues, earned income, philanthropic gifts and other fundraising activities, and may use these contributions to support general school and district operations or to finance particular programs. These school-supporting nonprofits are distinct from local education funds, community foundations, and independent foundations, which do not necessarily support K-12 public education at the local level. Local education funds "operate on a district, regional, or statewide level and act independently of the schools and districts themselves" and aim to achieve systematic education reforms rather than to provide local support for specific schools or districts (Hansen 2008, p. 317). Community foundations operate grants-based programs intended to address a broad set of community concerns and do not limit their programs to the support of public schools. Independent foundations are private philanthropic organizations that support K12 education; independent foundations usually do not operate at a local school or district level, and funding often is allocated toward research or advocacy (Hansen 2008).

As Hansen (2008) and Greene (2005) document, there are a number of challenges in estimating the level and distribution of voluntary contributions to public education. Some studies of voluntary contributions use financial data from tax-exempt nonprofit organizations, reported to the Internal Revenue Service on Form 990 if nonprofit revenues exceed $\$ 25,000$ per year. ${ }^{5}$ For example, Brunner and Sonstelie (2003) use IRS data from 1994 to examine voluntary contributions to California public schools, supplemented with information on nonprofit mission and type obtained from the California Registry of Charitable Trusts. Though they find voluntary contributions exceeding $\$ 1,000$ per pupil in some schools and districts, average district-level contributions were measured at $\$ 145$ per pupil in districts containing at least one schoolsupporting nonprofit that filed a Form 990. The authors conclude that “...contributions are not

\footnotetext{
${ }^{5}$ The filing threshold increased to $\$ 50,000$ in gross revenues in 2010 .
} 
large enough to substantially undermine school finance reform" and that "[e]ven when cooperation is substantial...voluntary collective action is a poor substitute for the taxing authority of local government” (p. 2159). Brunner and Imazeki (2005) update the California data through 2001 and find that — among districts containing at least one school-supporting nonprofit that filed a Form 990 — average per-pupil net revenues ranged from $\$ 188$ in high school districts, to \$274 in unified school districts, and \$489 in elementary districts. Averaging across all students in California public schools, they find that net revenues per pupil increased 62.5 percent, from \$24 in 1992 to \$39 in 2001. The authors reach a similar conclusion that “...it seems unlikely that contributions will ever be the source of wide-scale disruptions in the distribution of revenue across communities" (p. 51).

To estimate philanthropic giving to K-12 education nationally in 2002, Greene (2005) employs IRS 990 data reported by the 30 largest K-12 independent foundations as identified by the Foundation Center, supplemented with survey data obtained from the largest 100 U.S. public school districts. He finds that philanthropic contributions accounted for between $\$ 1.5$ and $\$ 2$ billion in 2002, as compared to overall K-12 spending of $\$ 427$ billion. Greene concludes that “...most current education philanthropy is just dumping buckets of water into the ocean of public school spending" (p. 74) and that private contributions to public schools "are simply too small to significantly raise the level of resources available to schools" (p. 49).

A significant body of research suggests that voluntary contributions to public education do not constitute a viable alternative to tax revenues and are not sufficiently sizable to overcome government failure. Despite this, the Great Recession precipitated large cutbacks in state aid to public schools and spurred renewed interest in revenues obtained from nongovernmental sources. Though sparse, more recent literature suggests voluntary contributions play a growing role in 
financing public education. Figlio and Kenny (2009) use data on voluntary contributions obtained from surveys of Florida elementary and middle school principals in 1999-2000, 200102, and 2003-04 and find that voluntary contributions in these years account for about 5 percent of K-12 revenues. ${ }^{6}$ Another recent analysis by the Public Policy Institute of California (PPIC) finds that voluntary contributions to California public schools — as measured by revenues reported on IRS Form 990-increased from \$70 million in 1989 to $\$ 1.3$ billion in 2007 ( $\mathrm{Su}$ 2012). Unusually large voluntary contributions - such as the $\$ 100$ million donation by social media billionaire Mark Zuckerberg to create the Foundation for Newark's Future in 2010receive substantial attention in the popular press.

Recent studies in public finance also highlight the growing importance of voluntary contributions to public education. Dye and Reschovsky (2008) find that, on average, local school districts are able to offset a dollar reduction in state aid with just 37 cents in local property taxes; similarly, Alm and Sjoquist (2009) find that Georgia school districts are able to offset every dollar reduction in state aid with 40 cents in locally raised revenues. Voluntary contributions may help public schools fill in this gap.

\section{Contribution}

This paper makes a number of contributions to the literature on voluntary contributions to public education. First, the paper updates the literature over the last decade using a panel of data on voluntary contributions to public schools from 1995 through 2010, a period that spans substantial variation in recessionary trends. In contrast to prior research, the paper employs panel (rather than cross-sectional) data with national (rather than statewide) coverage. The data enable a comprehensive examination of the levels and distribution of voluntary contributions over time

\footnotetext{
${ }^{6}$ Figlio and Kenny's (2009) survey data allow them to observe total voluntary contributions, including those from organizations that do not file a Form 990 (i.e., who have gross revenues less than $\$ 25,000$ ).
} 
and across districts and states. Second, the paper disaggregates voluntary contributions by type of supporting organization (PTA/PTO, booster, endowment, and school foundation). Third, the paper models both the probability that a school district receives revenues from a nonprofit, as well as the level of per-pupil voluntary contributions as a function of school district characteristics. Fourth, the paper examines whether and how voluntary contributions address government failure by offsetting reductions in state aid to public schools.

\section{DATA AND SAMPLE}

Our primary dataset contains 16,383 school-supporting nonprofit organizations that file annually with the Internal Revenue Service. We identified these organizations in 2012 using the 2008 Core Public Charity files provided by the National Center for Charitable Statistics (NCCS) and maintained in the Guidestar nonprofit database, which provides subscription access to data on more than 1.8 million tax-exempt U.S. organizations. The Guidestar data include information on organization type, mission, and location, as well as Form 990 filing data and expenditure reports for nonprofits with annual revenues totaling $\$ 25,000$ or more. We identified schoolsupporting nonprofits in the Guidestar database using keyword searches and National Taxonomy of Exempt Entities (NTEE) codes, developed by NCCS for classifying nonprofits according to mission. ${ }^{7}$ We excluded from our dataset any organizations that do not provide local support to schools or school districts (e.g., education nonprofits that support general education causes, private schools, serve multiple districts, or provide education services or resources at the

\footnotetext{
${ }^{7}$ Although the NCCS created the National Taxonomy of Exempt Entities (NTEE) coding protocols to provide a standardized means of identifying charitable organizations by their purpose, Guidestar assigns different codes and Gazley (2011) found that relying solely on select NTEE codes to identify these government-supporting entities was insufficient to capture all cases. In the absence of consistent identifiers, a keyword search was performed on the approximately 65,000 entities categorized under the NTEE code B for Educational Institutions (this category also includes libraries). Separately and in combination, keywords such as "friends", "education", "foundation", "school", "school district", "booster", "parent", "PTO" and "trust" were used to identify the school-supporting nonprofits.
} 
regional, state, or national levels), organizations whose missions do not support school or school district operations directly (e.g., organizations whose mission it is to provide college scholarships to graduating high school students), organizations without valid locational data, and organizations operationally miscategorized in Guidestar. Each organization was coded to identify whether it serves a school or school district; its type (PTA, PTO, booster, foundation, endowment, or other); and the type of school served by the organization (traditional public, magnet, charter, or private). In cases where nonprofit categorizations or addresses were ambiguous, we verified information by calling the organizations and/or cross-checking their websites by hand. ${ }^{8}$

We then linked each identified nonprofit organization to IRS panel data obtained from Form 990 filings for the years 1995 through 2010. The IRS data include total revenues by year for nonprofits with annual revenues exceeding $\$ 25,000$. Note that we do not observe voluntary contributions to school-supporting nonprofits that do not file a Form 990, so our data most likely significantly under-report voluntary contributions to public education (Figlio and Kenny 2009). ${ }^{9}$ We identify the presence of a school-supporting nonprofit in a given year if it reports revenues on its IRS Form 990.

\footnotetext{
${ }^{8}$ Our tabulation of school-supporting nonprofits differs from the NCCS tabulations. For example, we report 2,116 foundations in our data, as compared to the NCCS estimate of 9,093 registered foundations in the education category. This discrepancy is due to definitional differences. The NCCS figures include education foundations spanning 29 categories of support, including management and technical assistance, single organization support, fundraising and fund distribution, libraries, parent teacher groups, and scholarships and student financial aid. A good example of how the NCCS data tabulations differ from ours is found within the single organization support subcategory, which lists over 1,500 organization and is comprised mainly of athletic and music booster clubs. Our data tabulates these organizations separately and we do not include them within the count of school foundations. Further, the scholarships and student financial aid subcategory includes over 5,000 organizations. We exclude many of these organizations from our dataset because they do not provide direct support for school or district operations (e.g., their stated missions are to provide college scholarships to graduating high school seniors).

${ }^{9}$ Hansen (2008) notes that beginning in 2006, the U.S. Census Bureau's survey of school system finances requires school districts to report contributions and donations from private sources. Unfortunately, these data are not available for the full panel in our study and are not disaggregated by source.
} 
Next, we used ArcGIS 10 software and school district boundary shapefiles obtained from the National Center for Education Statistics (NCES) to geocode and match 96.1 percent of the nonprofit sample to the correct NCES school district ID using the street address of the school or school district office supported by each charitable organization. Note that local education nonprofits may provide support at either the school or district levels. We are unable to precisely match nonprofits to individual schools using address data because school catchment zone shapefiles are not available nationally. As a result, we aggregate school-supporting nonprofit data at the school district level - even in cases where nonprofits in our dataset support schoolspecific (rather than district-wide) activities. We view this aggregation as acceptable because revenues flowing to public schools are fungible within districts, in the sense that voluntary contributions made to particular schools may free up resources for other schools within the district.

We then used the NCES school district ID to merge the school-supporting nonprofit dataset to national panel data on unified school districts obtained from the NCES Common Core of Data (CCD), which are available from 1999 through 2010. The CCD panel data include total enrollment, expenditures per student, the percent of students enrolled in free and reduced-price meal programs (a measure of student poverty), the percent of English Learner students, and student-teacher ratios for each unified school district. We also constrain our analysis to schoolsupporting nonprofits that serve unified public school districts, due to difficulties in assigning nonprofits to districts in cases where district boundaries overlap (for example, in the case of overlapping elementary and high school districts) and due to differences in the funding of nonunified public school districts. 
Finally, we merge our dataset with NCES panel data obtained from the Local Education Agency (School District) Finance Survey (F-33) Data. ${ }^{10}$ The F-33 data report total district revenues by funding source. We use these data to calculate state revenues per pupil in each year from 1999 through 2010, and to calculate the change in state revenues per pupil from the prior year. We use these variables to answer our third research question: To what extent do voluntary contributions offset reductions in state aid to public schools?

Due to these additional data requirements, our final analysis sample includes a total of 13,058 unique school-supporting nonprofits. We use the Consumer Price Index to transform all variables measured in dollars (nonprofit revenues, per-pupil expenditures, and state revenues per pupil) to inflation-adjusted 2010 dollars. To account for outliers, we winsorize all variables at the 1\% extreme values of the distribution.

\section{THE RISE OF SCHOOL-SUPPORTING NONPROFITS}

We first examine changes in voluntary contributions to public schools from 1995 through 2010 using our primary dataset of 16,383 school-supporting nonprofits that file annually with the IRS. Table 1 displays school-supporting nonprofits by organization type. PTAs and PTOs constitute the majority -70.2 percent — of nonprofits in our dataset. Booster clubs and local school foundations constitute an additional 15.1 and 12.9 percent, while school endowments and other organizations comprise a very small share (less than two percent).

[Table 1 here]

\footnotetext{
${ }^{10}$ Though F-33 school finance data are available for the entire panel from 1995-2010, we only merge in school finance data for the years in which we also observe school district demographic data obtained from the NCES Common Core of Data (1999 through 2010).
} 
Table 2 partitions the school-supporting nonprofits in our dataset by the school type served. The vast majority of charities in our dataset—93.8 percent—support traditional public schools or districts; an additional 2.6 percent of charities support public magnet schools, while 1.3 percent support public charter schools. ${ }^{11}$

[Table 2 here]

Figure 1 presents the spatial distribution of school-supporting nonprofits in our dataset. School-supporting nonprofits in our sample have broad representation across the U.S., and their geographic distribution is denser in areas with higher population density.

[Figure 1 here]

Figure 2 illustrates tremendous growth in the number of school-supporting nonprofit IRS 990 filings from 1995 through 2010, overall and by organization type. Table 3 reports the corresponding percent increases in filings during the same time period, partitioned by organization type. Overall, the number of school-supporting nonprofits increased 230 percent, from 3,475 organizations in 1995 to 11,453 organizations in 2010 . Further, over the same time period, the number of 990 filings increased by at least 100 percent, and the growth was more than 300 percent for PTOs, school foundations, and booster club filings.

[Figure 2 here]

\footnotetext{
${ }^{11}$ Table 2 reports that 2.3 percent of charities in our dataset support private schools. We exclude these charities from our analysis sample because they do not support public schools or districts.
} 
[Table 3 here]

Figure 3 illustrates the growth in total (gross) revenues reported by school-supporting nonprofits filing an IRS Form 990 from 1995 through 2010, overall and by organization type. Table 4 reports the corresponding percent increases in revenues during the same time period. Overall, school-supporting nonprofit revenues increased 347.7 percent—from about $\$ 197$ million in 1995 to $\$ 880$ million in 2010 - and increased at a faster rate than nonprofit filings. Over the same time period, total revenues increased by at least 200 percent among PTOs, PTAs, school foundations, and boosters. PTOs and school foundations saw tremendous increases in total revenues, increasing over the time period by 527 and 485 percent, respectively.

[Figure 3 here]

[Table 4 here]

Finally, Table 5 reports growth in the representation of IRS-filing, school-supporting nonprofits in public school districts from 1995 through 2010. The percent of public school districts where at least one of these organizations operated increased from just 12 percent in 1995 to 29 percent in 2010. Over the same time period, the percent of school districts with a PTA or PTO increased from 9 to 20; the percent of school districts with a foundation increased from 2.2 to 8.5; and the percent of school districts with a booster club increased from 3.3 to 10.1 . 
[Table 5 here]

Research on school-supporting nonprofit 990 filings has not been updated since Brunner and Imazeki (2005), a study that relied on tax filing data available through 2001. The time trends reported in figures 2 and 3 indicate that the majority of growth in 990 filings and revenues has occurred since 2001, in the latter portion of the panel. The figure also reflects a peak in nonprofit filings and revenue levels in 2008 at the start of the Great Recession. This peak provides suggestive evidence that school-supporting nonprofits play more important roles during economic recessions, a hypothesis we test empirically in Section 6 by examining how nonprofit revenues vary with changes in state aid and per-pupil expenditures. Note, however, that the peak in observed in 2009 and 2010 may be artificial and temporary; the subsequent drop in tax filings and revenues observed in 2009 and 2010 should be interpreted with care, for two reasons. First, organizations that delayed filing a Form 990 in 2009 or 2010 may not appear in our dataset for those years. Second, the IRS increased the Form 990 filing threshold to $\$ 50,000$ in gross revenues in 2010; as a result, nonprofit organizations with revenues falling between the 2009 threshold of $\$ 25,000$ and the 2010 threshold of $\$ 50,000$ may not have filed a Form 990 in 2010. We address this sample truncation issue by excluding observations from 2010 in our subsequent empirical analyses.

\section{DISTRIBUTIONAL CONSEQUENCES OF NONPROFIT CONTRIBUTIONS}

In this section, we examine the distributional consequences of voluntary contributions to public schools. The presence of school-supporting nonprofits and the level of voluntary contributions to public schools are not uniform. The uneven distribution of charitable resources enables us to examine demand heterogeneity across school districts and associated equity 
implications, including whether the distribution of nonprofit revenues results in funding inequalities that are sufficiently large to undermine school finance equalization. To answer these questions, we employ panel data on school-supporting nonprofits linked to a complete panel of unified school district data for the years 1999 through 2009, in which we observe school district data obtained from the NCES Common Core of Data. Excluding observations from 2010 in our sample due to changes in 501(c)(3) IRS filing requirements, our final analysis sample includes 13,058 unique school-supporting nonprofits that meet the criteria for sample inclusion described in Section 3.

We first model the probability that a unified school district receives revenues from a schoolsupporting 501(c)(3) charity as a function of time-varying school district characteristics: the change in state revenues per pupil from the prior year, the log of total enrollment, the log of expenditures per student, the percent of students enrolled in free and reduced-price meal programs, the percent of English Learners, and student-teacher ratios. We begin with the following reduced-form model:

$$
Y_{d t}=\beta X_{d t}+\eta_{t}+\varepsilon_{d t}
$$

The dependent variable is a dichotomous variable indicating whether district $d$ receives any revenues from a school-supporting 501(c)(3) charity in year $t$ (i.e., whether any organization files an IRS Form 990 in the district in a given year), $X$ is a set of time-varying district characteristics, $\eta$ denotes year fixed effects and captures systematic differences in IRS filings over time, and $\varepsilon$ denotes the random error term. The coefficient $\beta$ is the average effect of that district characteristic on the probability of the district having at least one school-supporting nonprofit in a given year. We estimate a linear probability model using ordinary least squares (OLS) and robust standard errors to account for heteroskedasticity resulting from the application of OLS 
techniques to limited dependent variables. The model coefficients $\beta$ are descriptive and not causal, because unobserved district characteristics are likely to be correlated with both the observed district characteristics $(X)$ and with whether any organization files an IRS Form 990 in the district $(Y)$. Thus, omitting these variables is likely to bias estimates of the effects of district characteristics on our dependent variable of interest.

A major benefit of using panel data for our analysis is that it enables us to reduce bias in our estimated coefficients by including a rich set of fixed effects to control for time-invariant observed and unobserved variation nested within units. Our data have broad national coverage and span eleven years, so we are able to modify equation (1) to include additional fixed effects:

$$
Y_{d t}=\beta X_{d t}+\gamma_{d}+\eta_{t}+\varepsilon_{d t}
$$

In equation (2), $\gamma$ denotes a set of fixed effects, which may be specified at either the state level $s$ or at the school district level $d$. The fixed effects model reduces bias associated with timeinvariant observed and unobserved differences in states (districts) that may be correlated with both the time-varying district characteristics and our dependent variable. While this model reduces bias due to systematic differences in district characteristics across states (and in district characteristics over time), the estimated $\beta$ coefficients may still be biased due to time-varying unobservables at the district level. The inclusion of school district fixed effects in equation (2) requires that the $\beta$ coefficients are estimated using within-district variation in district characteristics, and net of time trends. Such a parameterization reduces bias but is likely to yield relatively imprecise estimates of $\beta$. Alternatively, a less restrictive parameterization with fixed effects at the state level will yield $\beta$ estimates that are more precise but relatively biased.

Notably, linear probability models are prone to problems arising from unbounded predicted values; as we observe in our models, estimated coefficients may take on values that are greater 
than one and less than negative one. However, we prefer the OLS specification to the standard logit or probit specification because it is not prone to the incidental parameters problem encountered when using maximum likelihood techniques in combination with fixed effects. In untabulated results, we run probit specifications without fixed effects to test the robustness of our reduced-form estimates to non-linear transformations.

Table 6 reports results from our linear probability regressions modeling whether a unified school district receives revenues from a school-supporting 501(c)(3) charity. Model I displays the reduced-form estimates, Model II displays results including state fixed effects, and Model III displays results including school district (rather than state) fixed effects.

[Table 6 here]

Coefficients on the year fixed effects confirm the descriptive trends in Table 5. The probability that a school district receives revenues from any school-supporting nonprofit increases monotonically from 1999 through 2008, before dropping off slightly in $2009 .{ }^{12}$ Depending on the model specification, the probability is between 0.09 and 0.16 higher in 2008 as compared to the 1999 baseline year.

The probability that any school-supporting nonprofit files an IRS Form 990 in a district is significantly higher in districts with higher per-pupil expenditures and higher enrollments. The reduced-form coefficients on these variables are underestimated relative to the state fixed effects model, but overestimated relative to the district fixed effects model. These relationships imply that within states, the probability of receiving revenues from a school-supporting nonprofit is more variable than across states. Unsurprisingly, the probability is less variable within districts

\footnotetext{
${ }^{12}$ As we discuss in Section 4, part of the decline in 2009 may be due to delays in IRS tax filings.
} 
over time, as we observe in the more restrictive district fixed effects model; however, estimated coefficients remain positive and statistically significant. Coefficients on other school district characteristics are less consistent across model specifications. For example, higher pupil-teacher ratios are associated with significantly lower probabilities of receiving revenues from a schoolsupporting nonprofit, but only in the state fixed effects model. The percent of English Learners in the district is associated with higher marginal probabilities of receiving revenues from a school-supporting nonprofit, but the effect is statistically significant in the district fixed effects model only. Finally, the percent of students in poverty (as measured by enrollment in free- and reduced-price meal programs) is associated with significantly lower probabilities of receiving school-supporting nonprofit revenues in the reduced-form and state fixed effect models, but the effect is not statistically significant in the district fixed effects model. Within-district variation in poverty may not be sufficiently large over time to identify the effect precisely. Taken together, the results generally indicate that relatively large districts with higher spending per pupil have higher probabilities of receiving revenues from a school-supporting nonprofit, while the probability is lower among districts serving higher proportions of students in poverty.

Table 7 reports results from additional regressions that model separately the probabilities that school districts receive revenues from any PTA/PTO, booster club, or school foundation. For each model, we report results from the reduced-form, state fixed effect, and district fixed effect specifications. The time trends observed closely match those reported in Table 6.

[Table 7 here] 
The probability that a school district receives revenues from a PTA/PTO, booster club, or school foundation is significantly higher in districts with higher student enrollments, regardless of the model specification. Coefficients on other time-varying district characteristics are more variable across models. For example, per-pupil spending positively and significantly predicts whether a district receives revenues from a PTA/PTO or from a school foundation, though the results are insignificant in the reduced-form specification of the school foundation model. Higher pupilteacher ratios are also associated with significantly lower probabilities of a district receiving revenues from a PTA/PTO or booster club in the state fixed effects specifications, indicating that within states, PTA/PTO and booster club nonprofits disproportionately serve districts with lower average class sizes. There is an interesting relationship between the percent of English Learners in a district and the probability of receiving revenues from a booster club or a school foundation. The percent of English Learners positively and significantly predicts these probabilities in the reduced form models but not in the state fixed effect models, indicating that cross-state differences in the distribution of English Learners largely explain the differences observed in the reduced form models. However, the percent of English Learners also positively and significantly predicts the probability of a district receiving booster club revenues in the district fixed effects regression. The findings suggest that within districts, an increase in the percent of English Learner students over time is associated with higher probabilities of districts receiving any revenue from a booster club. Finally, we find that the percent of students in poverty is associated with significantly lower probabilities of receiving school-supporting nonprofit revenues from a PTA/PTO, booster club, or school foundation in the reduced-form and state fixed effect models, but the effect is not statistically significant in the district fixed effects model. Again, it may be 
the case that within-district variation in poverty may not be sufficiently large over time to identify the effect precisely.

We next turn to modeling the level of per-pupil voluntary contributions at the district level as a function of school district characteristics. We adapt the reduced-form and fixed effects specifications in equations (1) and (2), changing the dependent variable $Y$ from a dichotomous outcome to a continuously defined measure of nonprofit revenues per pupil, calculated using total revenues across all nonprofits in the school district and dividing by the total number of enrolled students. We estimate our models using OLS. Because our dependent variable is no longer dichotomous, we no longer encounter problems in interpreting unbounded predicted coefficients; in addition, heterskedasticity is of less concern with a continuously defined dependent variable (though we continue to use robust standard errors in our models). We run our district-level models of per-pupil revenue conditional on the sample of districts that received revenues from a school-supporting organization (i.e., the sample of districts for which the dependent variable was equal to one in our first set of regressions in Table 6). This specification raises two issues. First, our data are left-censored because we do not observe revenues from school-supporting nonprofits that do not file with the IRS, and so (1) our analysis sample is likely to be truncated and (2) we are likely to under-estimate total per-pupil nonprofit revenues (Figlio and Kenny 2009). However, we are unable to employ a Tobit specification to account for this censoring because the likelihood estimator for fixed effects is biased and inconsistent. Second, the selection of school districts into our sample is non-random and will lead to biased coefficient estimates. However, we are unable to employ the results from our first set of regressions in Table 6 in a standard Heckman selection model because we do not observe 
variables in our dataset that form a valid exclusion restriction. Therefore, coefficient estimates should be interpreted with caution as descriptive rather than causal.

Table 8 reports our results modeling the level of per-pupil voluntary contributions (as measured by the average of district school-supporting nonprofit revenues) using the same specifications and school district characteristics as in the models reported in tables 6 and 7.

[Table 8 here]

Coefficients on the year fixed effects again confirm the time trends in Table 5. Per-pupil voluntary contributions increase monotonically in each year from 1999 through 2008 (and slightly decline in 2009). Notably, the time trends are the most sizable and statistically significant in the district fixed effects regression, suggesting that time trends within districts explain large differences in voluntary contributions. The district fixed effect regression suggests that within districts, average per-pupil voluntary contributions increased by nearly $\$ 30$ from 1999 through 2009.

Our results also provide support for Brunner and Sontelie's (2003) model of partial cooperation, which posits that the marginal price of voluntary contributions increases with the number of students enrolled in the district. Using California data, Brunner and Sonstelie (2003) find a negative cross-sectional relationship between per-pupil donations and enrollment, and Brunner and Imazeki (2005) confirm this relationship using an updated panel dataset but without additional controls. In our dataset, which includes national panel data from 1999 through 2009, we find a sizable and statistically significant negative relationship between per-pupil voluntary contributions - as measured by the revenues reported by nonprofits filing IRS Form 990 - and 
the log of district enrollment in both our reduced-form and state fixed effects models. The effect is statistically insignificant in the district fixed effects specification, suggesting that enrollment changes over time within districts and net of secular trends do not significantly predict the level of per-pupil voluntary contributions.

In our model of per-pupil voluntary contributions, coefficients on the remaining time-varying district characteristics shed additional light on the distributional consequences of nonprofit contributions. First, we find no evidence in any of our model specifications that per-pupil voluntary contributions vary significantly with the percent of English Learners in a school district. Second, we find that pupil-teacher ratios negatively and significantly predict voluntary contributions in our state fixed effects model, but positively and significantly predict voluntary contributions in our district fixed effects model. These results suggest that within states, districts with relatively high class sizes receive lower voluntary contributions on a per-pupil basis. However, within districts, class size increases over time are associated with higher average perpupil voluntary contributions. Third, we find that the percent of students in poverty is associated with significantly lower voluntary contributions per pupil across each of our model specifications. We discuss the coefficients on our financial variables of interest—state revenues per pupil and per pupil expenditures—in Section 6.

As final robustness check, we re-run our reduced-form, state fixed effects, and district fixed effects regressions using a first-differences model, where the dependent variable is defined as the change in per-pupil voluntary contributions from the prior year. Table 8 reports the results. Results from the first-differences model are similar to those observed in the model of per-pupil voluntary contributions. Coefficients on both time trend and district time-varying coefficients 
generally hold the same sign, though the statistical significance and magnitude of the effect sizes are different due to changes in the scale and variability of the dependent variable.

Taken together, results reported in tables 6,7 , and 8 indicate substantial growth in both the presence of school-supporting nonprofits and in the level of per-pupil voluntary contributions from 1999 through 2009, overall and by organization type. We also find that school districts with relatively high student enrollments and per-pupil expenditures have higher probabilities of being served by at least one school-supporting nonprofit, but that the level of per-pupil voluntary contributions declines with student enrollment. Higher-poverty school districts are less likely to be served by a school-supporting nonprofit; further, among school districts with at least one school-supporting nonprofit, higher-poverty school districts receive significantly lower voluntary contributions on a per-pupil basis.

\section{DO VOLUNTARY CONTRIBUTIONS REPLACE REDUCTIONS IN STATE AID?}

In this section, we examine whether voluntary contributions offset reductions in state aid to public schools. We address this research question by re-visiting the models of per-pupil voluntary contributions reported in Table 8 , and focus our attention on interpreting the coefficients on school district fiscal measures. The fiscal measures in both models capture some aspects of fiscal stress, enabling us to test empirically the responsiveness of voluntary contributions to recession.

The first set of regressions models per-pupil voluntary contributions as a function of timevarying district characteristics and year fixed effects. The time-varying district characteristics include two fiscal variables - state revenues per pupil and the log of per-pupil expenditureswhich form our policy variables of interest. We find no evidence of a statistically significant relationship between per-pupil expenditures and per-pupil voluntary contributions. However, we 
find that higher state revenues per pupil are associated with lower per-pupil voluntary contributions. This relationship — which holds across the reduced-form, state fixed effects, and district fixed effects specifications-implies that voluntary contributions are higher when school districts face recessionary reductions in state aid. The persistence of this relationship in the district fixed effects specification indicates that within-district reductions in state aid per pupil over time are associated with higher levels of per-pupil voluntary contributions. However, the magnitude of the effect is not economically meaningful: a $\$ 100$ increase in state revenues per pupil is associated with reductions in per-pupil voluntary contributions ranging from 20 to 32 cents. Although the relationship we estimate is descriptive and not causal, it is difficult to imagine a scenario in which additional bias-reduction techniques---namely, via a two-stage Heckman selection model or through the inclusion of additional time-varying district characteristics-would change the coefficients so substantially as to render them economically meaningful. Even large changes in the parameterization of our models-from a reduced-form specification to a district fixed effects specification-yield changes in coefficient estimates that amount to pennies on the dollar.

As a robustness check, we run a second set of regressions in which we define the dependent variable as the change in per-pupil voluntary contributions from the prior year. We use the same set of control variables as in the first set of regressions, but we difference our two fiscal variables so they measure (1) changes in state revenues per pupil from the prior year, and (2) changes in per-pupil expenditures from the prior year. In these models, we find no evidence of a statistically significant relationship between the differenced dependent variable and the differenced fiscal variables. In summary, we find a negative but economically meaningless relationship between state aid per pupil and per-pupil voluntary contributions, a finding which implies that voluntary 
contributions do not offset reductions in state aid and do not constitute an efficient or stable substitute for the financing of K-12 public education.

\section{VOLUNTARY CONTRIBUTIONS: STILL BUCKETS INTO THE SEA?}

We now revisit the question of whether the rise in voluntary contributions is sufficiently substantial to change the distribution of funding across school districts and to undo school finance equalization. We first aggregate total school-supporting nonprofit revenues across all unified public school districts in the U.S. and divide this figure by total student enrollment in these districts. At the beginning of our panel in 1995, per-pupil voluntary contributions in the U.S. were $\$ 3.67$; by 2010 , the amount increased to $\$ 20.31$. Conditioning on only those unified school districts with at least one school-supporting nonprofit, we find average per-pupil voluntary contributions of $\$ 8.02$ in 1995 , a figure that grew to $\$ 28.38$ in $2010 .{ }^{13}$ Despite this tremendous growth, voluntary contributions to public schools — as measured by IRS Form 990 filings - remain a small fraction of total per pupil dollars spent on public education; in 2010, U.S. K-12 public schools spent an average of $\$ 10,615$ per student (Dixon 2012). Moreover, cross-district variation in voluntary contributions is unlikely to undermine school finance equalization. As one example, the Serrano v. Priest decision in California places statutory limits on differences in per-pupil expenditures across districts, but the limit — set at about $\$ 300$ — is far higher than average levels of per-pupil voluntary contributions.

Unfortunately, the 2010 changes in IRS Form 990 filing requirements will complicate future attempts to examine changes in voluntary contributions to public schools using a consistent source of data. However, relatively new sources of data on voluntary contributions — such as the U.S. Census Bureau's survey of school system finances that began in 2006-may reveal

\footnotetext{
${ }^{13}$ We report all dollar figures using inflation-adjusted 2010 dollars.
} 
significantly higher levels of voluntary contributions than are observed when relying on IRS Form 990 data. $^{14}$

Finally, our low average levels of per-pupil voluntary contributions belie the influential effect of school-supporting nonprofit activity within districts, where voluntary contributions may have sizable effects on the particular students or programs that benefit disproportionately from such funding. ${ }^{15}$ Recent anecdotal evidence suggests school districts are concerned increasingly with the uneven distribution of nonprofit revenues across schools. For example, California's Santa Monica - Malibu, Manhattan Beach, and Palo Alto school districts recently adopted policies to pool voluntary contributions at the district level for redistribution across schools (The Center for Investigative Reporting 2012).

\section{CONCLUSION}

In recent years, considerable scholarly and practitioner discussion has focused on the role of coproductive and philanthropic activity in public service provision. Our trend data make it clear that communities depend increasingly on philanthropic revenue to support public education. By 2010, school foundations and booster clubs alone have grown to represent more than one-quarter of all school-supporting nonprofits and to raise more than half of the $\$ 880$ million in 2010 revenue that these charities contributed to public education. Our findings also generally indicate that relatively large districts with higher spending per pupil have higher probabilities of receiving revenues from a school-supporting nonprofit, but that the level of per-pupil voluntary contributions declines with student enrollment. Higher-poverty school districts are less likely to

\footnotetext{
${ }^{14}$ Figlio and Kenny (2009) discuss the limitations of IRS Form 990 data in producing accurate estimates of voluntary contributions to public schools.

${ }^{15}$ Low average levels of per-pupil funding also may belie the influential effect of school-supporting nonprofit activity across districts that may only be observed in a less parametric context (e.g., in quintile regressions). We leave this possibility to future research.
} 
be served by a school-supporting nonprofit; further, among school districts with at least one school-supporting nonprofit, higher-poverty school districts receive significantly lower voluntary contributions on a per-pupil basis. These associations between school philanthropy and district wealth and size prevail after accounting for district and state fixed effects, although the effect sizes vary.

Finally, impressive recent growth in the number and financial size of these school supporting charities since 1995 has not offset reductions in state aid. Moreover, we do not find sufficient evidence to conclude that voluntary contributions change the distribution of funding across school districts and undo school finance equalization. 


\section{REFERENCES}

Alm, James, and David L. Sjoquist. 2009. The Response of Local School Systems in Georgia to Fiscal and Economic Conditions. Journal of Education Finance 35(1):60-84.

Andreoni, James. 1988. Privately provided public goods in a large economy: the limits of altruism. Journal of Public Economics 35(1):57-73.

Andreoni, James. 1989. Giving with impure altruism: applications to charity and Ricardian equivalence. Journal of Political Economy 97(6):1447-1458.

Andreoni, James. 1990. Impure altruism and donations to public goods: a theory of warm-glow giving. Economic Journal 100(401):464-477.

Bergstrom, Ted, Larry Blume, and Hal Varian. 1986. On the private provision of public goods. American Economic Review 63(3):280-296.

Brandsen, Taco, and Philip Marcel Karré. 2011. Hybrid organizations: No cause for concern? International Journal of Public Administration 34(13):827-36.

Brudney, Jeffrey L. 1987. Coproduction and privatization: exploring the relationship and its implications. Nonprofit and Voluntary Sector Quarterly 16(3):11-21.

Brudney, Jeffrey L., and Robert E. England. 1983. Toward a definition of the coproduction concept. Public Administration Review 43(1):59-65.

Brunner, Eric, and Jennifer Imazeki. 2005. Fiscal stress and voluntary contributions to schools. Developments in School Finance. National Center for Education Statistics. Washington, D.C.: U.S. Department of Education. http://wwwrohan.sdsu.edu/ jimazeki/papers/NCESDevelopments2005.pdf

Brunner, Eric, and John Sonstelie. 2003. Journal of Public Economics 87(9-10):2157-2185.

Center for Investigative Reporting. Foundations funding more basic school needs: California K12 foundations, PTAs and booster clubs raised about 1.3 billion. Available at:

http://www.utsandiego.com/news/2012/jan/19/foundations-funding-more-basic-schoolneeds/all/?print

Cohen, Rick. April 13, 2012. Philanthropy Funding Government Work? There's a Foundation for That-Several, Actually. Nonprofit Quarterly. Available at: http://www.nonprofitquarterly.org/policysocial-context/20145-philanthropy-fundinggovernment-work-theres-a-foundation-for-thatseveral-actually.html\#jacommentid:5148

Cornes, Richard, and Todd Sandler. 2984. Easy riders, joint production, and public goods. Economic Journal 94(275):580-598. 
Dixon, Mark. 2012. Public Education Finances 2010. United States Census Bureau. Available at: http://www2.census.gov/govs/school/10f33pub.pdf

Dye, Richard F., and Andrew Reschovsky. 2008. Property Tax Responses to State Aid Cuts in the Recent Fiscal Crisis. Public Budgeting \& Finance 28(2):87-111.

Figlio, David N., and Lawrence W. Kenny. 2009. Public sector performance management and stakeholder support. Journal of Public Economics 93(9-10:1069-1077.

Gazley, Beth. 2011. Cooptation, Coproduction, or Competition? A preliminary empirical look at government-supporting NPOs. Versions of this paper presented at the International Research Society for Public Management, Dublin IRELAND, April 12, 2011 and at the Association for Research on Nonprofit Organizations and Voluntary Action, Toronto, CANADA, November 17, 2011.

Glazer, Amihai, and Kai Konrad. 1996. A signaling explanation for charity. American Economic Review 86(4):1019-1028.

Greene, Jay. 2005. Buckets into the sea: why philanthropy isn't changing schools, and how it could. In With the Best of Intentions, edited by Frederick M. Hess. Cambridge, MA: Harvard Education Press, pp. 49-76.

Hansen, Janet S. 2008. The role of nongovernmental organizations in financing public schools. In Handbook of Research in Education Finance and Policy, edited by Helen F. Ladd and Edward B. Fiske. New York: Routledge, pp. 314-331.

Harbaugh, William T. 1998. What do donations buy? A model of philanthropy based on prestige and warm glow. Journal of Public Economics 67(2):269-284.

Irvin, Renee A., and Patrick Carr. 2005. The role of philanthropy in local government finance. Public Budgeting \& Finance 25(3):33-47.

Jetté, Christian, and Yves Vaillancourt. 2011. Social economy and home care services in Quebec: Co-production or co-construction? Voluntas 22(1):48-69.

Johnson, Nicholas, and Michael Leachman. 2013. Four big threats to state finances could undermine future U.S. prosperity. Washington, DC: Center for Budget and Policy Priorities. http://www.cbpp.org/cms/index.cfm?fa=view\&id=3903

Lampkin, Linda, and David Stern. November 2003. Who helps public schools: A portrait of local education funds, 1991 - 2001. Washington, D.C.: The Urban Institute.

Lecy, Jesse D., and David M. Van Slyke. 2013. Nonprofit sector growth and density: Testing theories of government support. Journal of Public Administration Research and Theory 23(1):189-214. 
Ledyard, John O. 1995. Public goods: a survey of experimental research. In Handbook of Experimental Economics, edited by John H. Kagel and Alvin E. Roth. Princeton: Princeton University Press, pp. 111-194.

Matsunaga, Yoshiho, and Naoto Yamauchi. 2004. Is the government failure theory still relevant? A panel analysis using US state level data. Annals of Public and Cooperative Economics 75(2):227-263.

McNichol, Elizabeth, Phil Oliff, and Nicholas Johnson. 2012. States Continue to Feel Recession's Impact. Washington, D.C.: Center on Budget and Policy Priorities. Last modified February 27, 2012. http://www.cbpp.org/cms/?fa=view\&id=711.

Mizrahi, Shlomo. 2011. Self-provision of public services: Its evolution and impact. Public Administration Review 71(2):285-91.

National Center for Education Statistics. 2013. National Public Education Financial Survey Data. Common Core of Data. Washington, D.C.: U.S. Department of Education. http://nces.ed.gov/datatools/index.asp?Data-\%20ToolSectionID=5.

Olson, Mancur, and Richard Zeckhauser. 1966. An economic theory of alliances. Review of Economics and Statistics 48(3):266-279.

O’Toole, Laurence J., and Kenneth J. Meier. 2004. Desperately seeking Selznick: Cooptation and the dark side of public management in networks. Public Administration Review 64(6):681-93.

Paarlberg, Laurie E., and Shelden Gen. 2009. Exploring the determinants of nonprofit coproduction of public service delivery: The case of K-12 public education. The American Review of Public Administration 39(4):391-408.

Parks, Roger B., Paula D. Baker, Larry Kiser, Ronald Oakerson, Elinor Ostrom, Vincent Ostrom, Stephen L. Percy, Martha B. Vandivort, Gordon P. Whitaker, and Rick Wilson. 1981. Consumers as co-producers of public services: some economic and institutional considerations. Policy Studies Journal 9(7):1001-1011.

Reschovsky, Andrew. Forthcoming, 2013. The future role of the property tax in the funding of K-12 education in the U.S. In Local Education, Land, and Location, edited by Gregory Ingram and Daphne Kenyon. Cambridge, MA: Lincoln Institute for Land Policy.

Roberts, Russell D. 1984. A positive model of private charity and wealth transfers. Journal of Political Economy 92(1):136-148.

Salamon, Lester M. 1987. Of market failure, voluntary failure, and third-party government: Toward a theory of government-nonprofit relations in the modern welfare state. Nonprofit and Voluntary Sector Quarterly 16(1-2):29-49. 
Steinberg, Richard. 1987. Voluntary donations and public expenditures in a federalist system. American Economic Review 77(1):24-36.

Su, Eleanor Yang. January 19, 2012. Public schools increasingly rely on private donations. http://abclocal.go.com/kgo/story?section=news/state\&id=8511564

Sugden, Robert. 1982. On the economics of philanthropy. Economic Journal 92(366):341-350.

Warr, Peter G. 1983. The private provision of a public good is independent of the distribution of income. Economics Letters 13(3):207-211.

Warren, Robert. 1987. Coproduction, volunteerism, privatization, and the public interest. Nonprofit and Voluntary Sector Quarterly 16(3):5-10.

Whitaker, Gordon P. 1980. Coproduction: citizen participation in service delivery. Public Administration Review 40(3):240-246.

Young, Dennis, R. 2000. Alternative models of government-nonprofit sector relations: theoretical and international perspectives. Nonprofit and Voluntary Sector Quarterly 29(1):149-172.

Zimmer, Ron, Cathy Krop, and Dominic Brewer. 2003. Private resources in public schools: Evidence from a pilot study. Journal of Education Finance 28:485-521. 
Table 1. School-Supporting Nonprofits by Organization Type

\begin{tabular}{lrr}
\hline Type & Number & Percent \\
\hline Boosters & 2,480 & $15.1 \%$ \\
Foundations & 2,116 & $12.9 \%$ \\
Endowments & 44 & $0.3 \%$ \\
PTA & 8,121 & $49.6 \%$ \\
PTO & 3,373 & $20.6 \%$ \\
Other & 249 & $1.5 \%$ \\
\hline Total & 16,383 & $100.0 \%$ \\
\hline
\end{tabular}

Table 2. School-Supporting Nonprofits by School Type

\begin{tabular}{lrr}
\hline Type & Number & Percent \\
\hline Public & 15,364 & $93.8 \%$ \\
Private & 377 & $2.3 \%$ \\
Public magnet & 426 & $2.6 \%$ \\
Public charter & 207 & $1.3 \%$ \\
Unknown & 9 & $0.1 \%$ \\
\hline Total & 16,383 & $100.0 \%$ \\
\hline
\end{tabular}


Figure 1. Spatial Distribution of School-Supporting Nonprofits

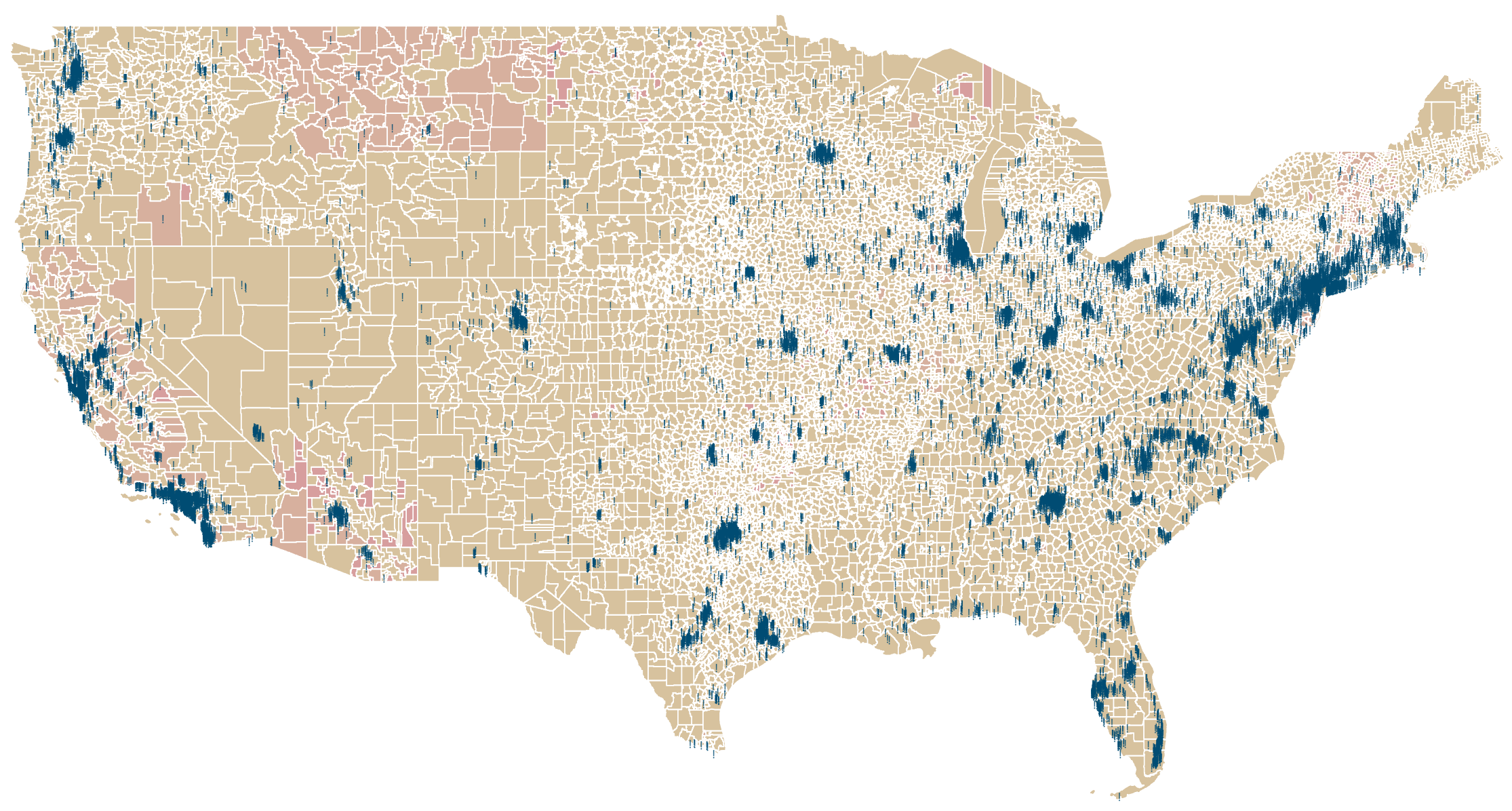


Figure 2. Time Series of School-Supporting Nonprofits by Organization Type ${ }^{a}$

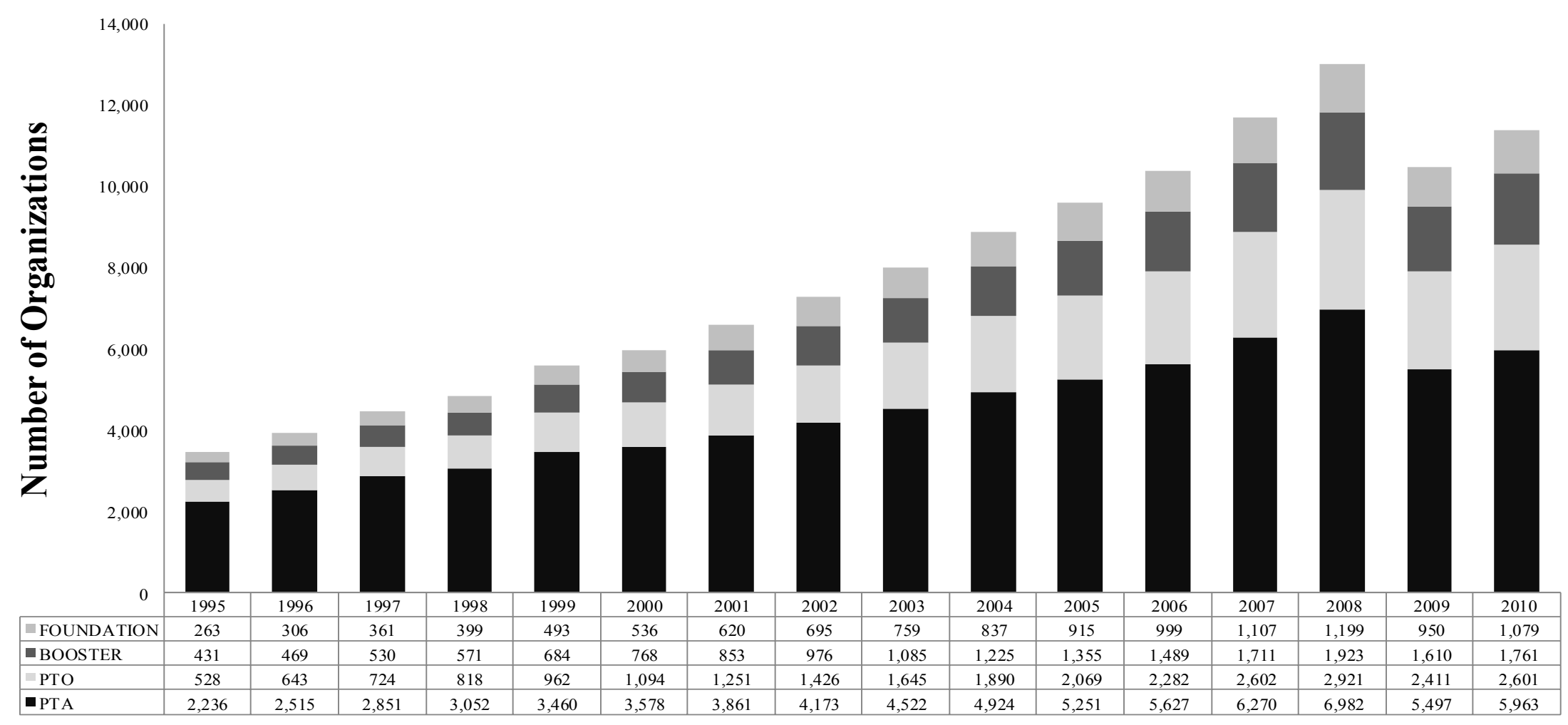

${ }^{\text {a }}$ The dropoff in number of filing organizations in 2009 and 2010 is most likely due to delays in filing 990 Forms. 
Figure 3. Time Series of School-Supporting Nonprofit Revenues by Organization Type

\section{Revenue by Organization Type and Year}

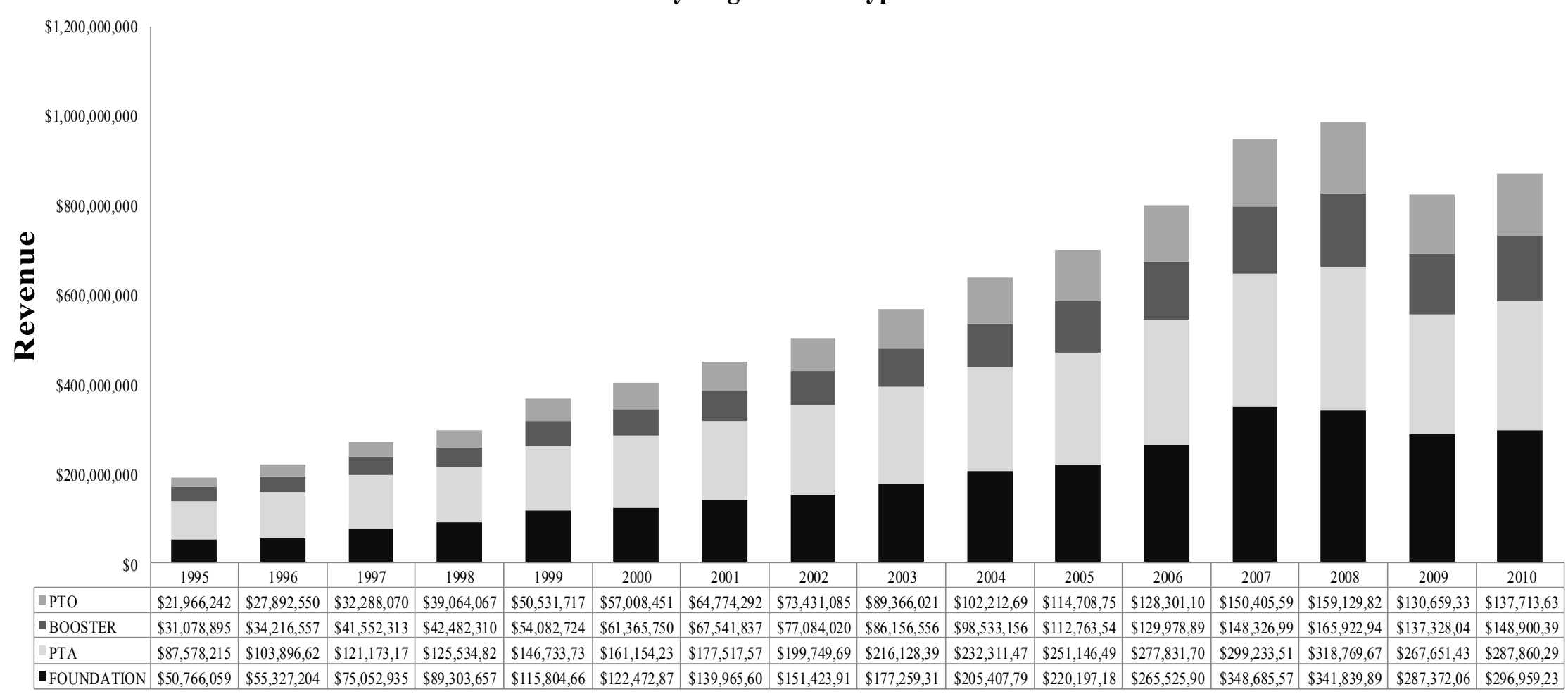


Table 3. Growth in School-Supporting Nonprofits, 1995 - 2010

\begin{tabular}{lrrr}
\hline & Organizations, 1995 & Organizations, 2010 & $\begin{array}{r}\text { Percent increase in } \\
\text { organizations, }\end{array}$ \\
\hline PTOs & 528 & 2,601 & $392.6 \%$ \\
LEFs & 263 & 1,079 & $310.3 \%$ \\
Boosters & 431 & 1,761 & $308.6 \%$ \\
Other & 6 & 24 & $300.0 \%$ \\
PTAs & 2,236 & 5,963 & $166.7 \%$ \\
Endowments & 11 & 25 & $127.3 \%$ \\
\hline Total & 3,475 & 11,453 & $229.6 \%$ \\
\hline
\end{tabular}

Table 4. Growth in School-Supporting Nonprofit Revenues, 1995-2010

\begin{tabular}{lrrr}
\hline & Revenue, 1995 & Revenue, 2010 & $\begin{array}{r}\text { Percent increase in } \\
\text { revenue, 1995-2010 }\end{array}$ \\
\hline PTOs & $\$ 21,966,242$ & $\$ 137,713,636$ & $526.9 \%$ \\
LEFs & $\$ 50,766,059$ & $\$ 296,959,231$ & $485.0 \%$ \\
Boosters & $\$ 31,078,895$ & $\$ 148,900,391$ & $379.1 \%$ \\
PTAs & $\$ 87,578,215$ & $\$ 287,860,297$ & $228.7 \%$ \\
Other & $\$ 2,763,032$ & $\$ 5,545,986$ & $100.7 \%$ \\
Endowments & $\$ 2,452,346$ & $\$ 3,146,526$ & $28.3 \%$ \\
\hline Total & $\$ 196,604,789$ & $\$ 880,126,067$ & $347.7 \%$ \\
\hline
\end{tabular}


Table 5. Growth in School-Supporting Nonprofit Representation, 1995-2010

\begin{tabular}{cccccc}
\hline \multicolumn{5}{c}{ Proportion of School Districts with a School-Supporting Nonprofit, by Organization } \\
\hline Year & Any & PTA/PTO & Type and Year & & \\
\hline 1995 & 0.1207 & 0.0899 & 0.0218 & 0.0326 & 0.0010 \\
1996 & 0.1317 & 0.0997 & 0.0253 & 0.0353 & 0.0010 \\
1997 & 0.1452 & 0.1094 & 0.0295 & 0.0391 & 0.0012 \\
1998 & 0.1556 & 0.1150 & 0.0330 & 0.0424 & 0.0012 \\
1999 & 0.1729 & 0.1253 & 0.0400 & 0.0488 & 0.0014 \\
2000 & 0.1816 & 0.1314 & 0.0437 & 0.0545 & 0.0014 \\
2001 & 0.1946 & 0.1385 & 0.0506 & 0.0584 & 0.0017 \\
2002 & 0.2112 & 0.1493 & 0.0564 & 0.0653 & 0.0016 \\
2003 & 0.2256 & 0.1604 & 0.0614 & 0.0714 & 0.0019 \\
2004 & 0.2397 & 0.1703 & 0.0668 & 0.0780 & 0.0020 \\
2005 & 0.2530 & 0.1781 & 0.0726 & 0.0848 & 0.0020 \\
2006 & 0.2692 & 0.1879 & 0.0785 & 0.0909 & 0.0022 \\
2007 & 0.2920 & 0.2034 & 0.0868 & 0.1004 & 0.0023 \\
2008 & 0.3109 & 0.2161 & 0.0938 & 0.1090 & 0.0024 \\
2009 & 0.2718 & 0.1930 & 0.0754 & 0.0943 & 0.0020 \\
2010 & 0.2885 & 0.2007 & 0.0849 & 0.1014 & 0.0023 \\
\hline
\end{tabular}


Table 6. The Distribution of School-Supporting Nonprofits

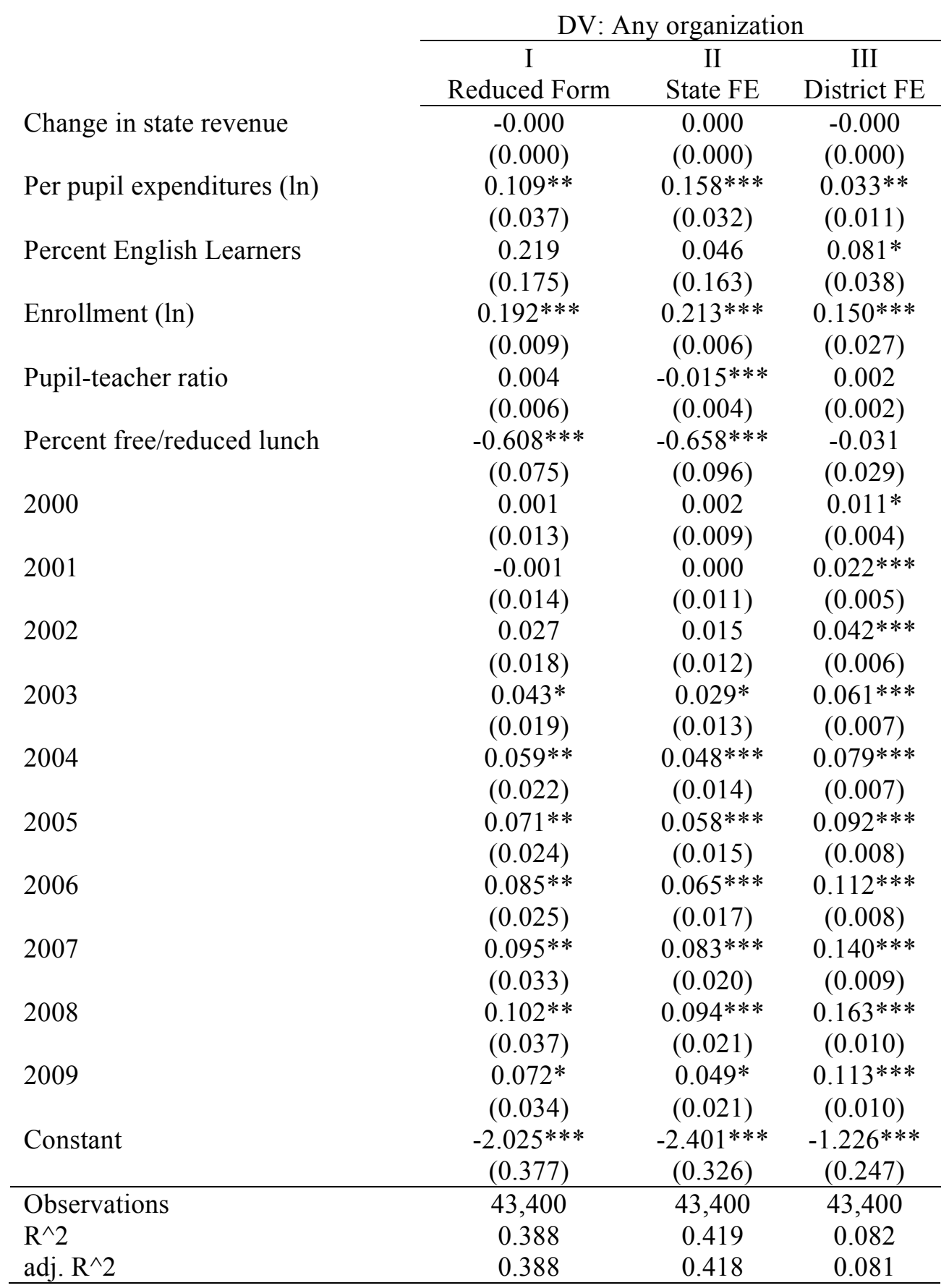

$* \mathrm{p}<.1 ; * * \mathrm{p}<.05 ; * * * \mathrm{p}<.01$ 
Table 7. The Distribution of School-Supporting Nonprofits, by Organization Type

\begin{tabular}{|c|c|c|c|c|c|c|c|c|c|}
\hline & \multicolumn{3}{|c|}{ DV: Any PTA/PTO } & \multicolumn{3}{|c|}{ DV: Any Booster } & \multicolumn{3}{|c|}{ DV: Any School Foundation } \\
\hline & $\begin{array}{c}\text { IV } \\
\text { Reduced } \\
\text { Form } \\
\end{array}$ & $\begin{array}{c}\text { V } \\
\text { State FE }\end{array}$ & $\begin{array}{c}\text { VI } \\
\text { District } \\
\text { FE }\end{array}$ & $\begin{array}{c}\text { VII } \\
\text { Reduced } \\
\text { Form } \\
\end{array}$ & $\begin{array}{c}\text { VIII } \\
\text { State FE }\end{array}$ & $\begin{array}{c}\text { IX } \\
\text { District } \\
\text { FE } \\
\end{array}$ & $\begin{array}{c}\mathrm{X} \\
\text { Reduced } \\
\text { Form } \\
\end{array}$ & $\begin{array}{c}\text { XI } \\
\text { State FE }\end{array}$ & $\begin{array}{c}\text { XII } \\
\text { District } \\
\text { FE }\end{array}$ \\
\hline \multirow[t]{2}{*}{ Change in state revenue } & -0.000 & 0.000 & -0.000 & -0.000 & 0.000 & 0.000 & $-0.000 *$ & 0.000 & 0.000 \\
\hline & $(0.000)$ & $(0.000)$ & $(0.000)$ & $(0.000)$ & $(0.000)$ & $(0.000)$ & $(0.000)$ & $(0.000)$ & $(0.000)$ \\
\hline \multirow[t]{2}{*}{ Per pupil expenditures (ln) } & $0.133 * * *$ & $0.162 * * *$ & $0.020 *$ & -0.058 & 0.024 & -0.004 & -0.025 & $0.091 * * *$ & $0.019 * *$ \\
\hline & $(0.035)$ & $(0.036)$ & $(0.009)$ & $(0.033)$ & $(0.020)$ & $(0.007)$ & $(0.034)$ & $(0.015)$ & $(0.007)$ \\
\hline \multirow[t]{2}{*}{ Percent English Learners } & 0.339 & 0.151 & 0.048 & $0.163^{*}$ & 0.047 & $0.052 *$ & $0.176^{*}$ & 0.032 & 0.036 \\
\hline & $(0.186)$ & $(0.174)$ & $(0.032)$ & $(0.066)$ & $(0.064)$ & $(0.026)$ & $(0.079)$ & $(0.065)$ & $(0.024)$ \\
\hline \multirow[t]{2}{*}{ Enrollment (ln) } & $0.177 * * *$ & $0.194 * * *$ & $0.146 * * *$ & $0.100 * * *$ & $0.114 * * *$ & $0.168 * * *$ & $0.068 * * *$ & $0.083 * * *$ & $0.086 * * *$ \\
\hline & $(0.012)$ & $(0.009)$ & $(0.025)$ & $(0.008)$ & $(0.007)$ & $(0.025)$ & $(0.006)$ & $(0.005)$ & $(0.026)$ \\
\hline \multirow[t]{2}{*}{ Pupil-teacher ratio } & 0.001 & $-0.017 * * *$ & 0.000 & -0.002 & $-0.016 * * *$ & -0.001 & -0.001 & $-0.008 * * *$ & -0.000 \\
\hline & $(0.007)$ & $(0.005)$ & $(0.001)$ & $(0.004)$ & $(0.003)$ & $(0.001)$ & $(0.002)$ & $(0.002)$ & $(0.001)$ \\
\hline \multirow[t]{2}{*}{$\begin{array}{l}\text { Percent free/reduced } \\
\text { lunch }\end{array}$} & $-0.603 * * *$ & $-0.685 * * *$ & -0.022 & $-0.192 * * *$ & $-0.280 * * *$ & 0.001 & $-0.123 * *$ & $-0.158 * * *$ & -0.003 \\
\hline & $(0.090)$ & $(0.115)$ & $(0.024)$ & $(0.038)$ & $(0.037)$ & $(0.020)$ & $(0.035)$ & $(0.036)$ & $(0.017)$ \\
\hline \multirow[t]{2}{*}{2000} & -0.004 & -0.008 & 0.002 & 0.001 & 0.004 & $0.010 * *$ & 0.004 & 0.002 & $0.010 * *$ \\
\hline & $(0.015)$ & $(0.009)$ & $(0.004)$ & $(0.007)$ & $(0.006)$ & $(0.003)$ & $(0.006)$ & $(0.004)$ & $(0.003)$ \\
\hline \multirow[t]{2}{*}{2001} & -0.021 & -0.016 & $0.010^{*}$ & $0.022^{*}$ & 0.007 & $0.014 * * *$ & $0.015^{*}$ & 0.004 & $0.018 * * *$ \\
\hline & $(0.015)$ & $(0.011)$ & $(0.004)$ & $(0.010)$ & $(0.007)$ & $(0.004)$ & $(0.006)$ & $(0.004)$ & $(0.004)$ \\
\hline \multirow[t]{2}{*}{2002} & 0.000 & -0.009 & $0.025 * * *$ & $0.036 * *$ & 0.015 & $0.025 * * *$ & $0.022 * *$ & 0.005 & $0.025 * * *$ \\
\hline & $(0.021)$ & $(0.013)$ & $(0.005)$ & $(0.013)$ & $(0.009)$ & $(0.005)$ & $(0.008)$ & $(0.005)$ & $(0.004)$ \\
\hline \multirow[t]{2}{*}{2003} & 0.010 & 0.004 & $0.041 * * *$ & $0.050 * * *$ & $0.025^{*}$ & $0.036 * * *$ & $0.028 * *$ & 0.007 & $0.032 * * *$ \\
\hline & $(0.022)$ & $(0.014)$ & $(0.005)$ & $(0.013)$ & $(0.010)$ & $(0.005)$ & $(0.008)$ & $(0.006)$ & $(0.004)$ \\
\hline \multirow[t]{2}{*}{2004} & 0.023 & 0.022 & $0.058 * * *$ & $0.070 * * *$ & $0.041 * * *$ & $0.047 * * *$ & $0.040 * * *$ & $0.013^{*}$ & $0.039 * * *$ \\
\hline & $(0.025)$ & $(0.016)$ & $(0.006)$ & $(0.016)$ & $(0.010)$ & $(0.005)$ & $(0.011)$ & $(0.006)$ & $(0.005)$ \\
\hline \multirow[t]{2}{*}{2005} & 0.025 & 0.024 & $0.065 * * *$ & $0.088 * * *$ & $0.049 * * *$ & $0.058 * * *$ & $0.055 * * *$ & $0.019 *$ & $0.046^{* * *}$ \\
\hline & $(0.026)$ & $(0.017)$ & $(0.006)$ & $(0.018)$ & $(0.012)$ & $(0.006)$ & $(0.012)$ & $(0.007)$ & $(0.005)$ \\
\hline 2006 & 0.028 & 0.021 & $0.077 * * *$ & $0.093 * * *$ & $0.054 * * *$ & $0.066^{* * *}$ & $0.059 * * *$ & $0.019 *$ & $0.053 * * *$ \\
\hline
\end{tabular}




\begin{tabular}{lcccccccccc} 
& $(0.030)$ & $(0.019)$ & $(0.007)$ & $(0.018)$ & $(0.014)$ & $(0.006)$ & $(0.013)$ & $(0.008)$ & $(0.006)$ \\
2007 & 0.023 & 0.030 & $0.098^{* * *}$ & $0.105^{* * *}$ & $0.066^{* * *}$ & $0.082^{* * *}$ & $0.067^{* * *}$ & $0.022^{*}$ & $0.061^{* * *}$ \\
& $(0.037)$ & $(0.023)$ & $(0.008)$ & $(0.022)$ & $(0.015)$ & $(0.007)$ & $(0.016)$ & $(0.009)$ & $(0.006)$ \\
2008 & 0.027 & 0.035 & $0.114^{* * *}$ & $0.110^{* * *}$ & $0.073^{* * *}$ & $0.095^{* * *}$ & $0.078^{* * *}$ & $0.024^{*}$ & $0.068^{* * *}$ \\
& $(0.041)$ & $(0.025)$ & $(0.008)$ & $(0.024)$ & $(0.016)$ & $(0.007)$ & $(0.019)$ & $(0.010)$ & $(0.006)$ \\
2009 & 0.016 & 0.012 & $0.085^{* * *}$ & $0.107^{* * *}$ & $0.058^{* *}$ & $0.075^{* * *}$ & $0.055^{* *}$ & -0.002 & $0.045^{* * *}$ \\
& $(0.039)$ & $(0.025)$ & $(0.009)$ & $(0.026)$ & $(0.017)$ & $(0.008)$ & $(0.019)$ & $(0.010)$ & $(0.007)$ \\
Constant & $-2.149 * * *$ & $-2.320^{* * *}$ & $-1.116^{* * *}$ & -0.103 & $-0.774^{* * *}$ & $-1.218^{* * *}$ & -0.196 & $-1.220^{* * *}$ & $-0.794^{* * *}$ \\
& $(0.365)$ & $(0.389)$ & $(0.233)$ & $(0.290)$ & $(0.191)$ & $(0.216)$ & $(0.308)$ & $(0.128)$ & $(0.213)$ \\
\hline Observations & 43,400 & 43,400 & 43,400 & 43,400 & 43,400 & 43,400 & 43,400 & 43,400 & 43,400 \\
$\mathrm{R}^{\wedge} 2$ & 0.379 & 0.417 & 0.062 & 0.164 & 0.212 & 0.050 & 0.088 & 0.133 & 0.035 \\
adj. $\mathrm{R}^{\wedge 2}$ & 0.378 & 0.416 & 0.062 & 0.163 & 0.211 & 0.050 & 0.087 & 0.132 & 0.034 \\
\hline
\end{tabular}

$* \mathrm{p}<.1 ; * * \mathrm{p}<.05 ; * * * \mathrm{p}<.01$ 


\section{Table 8. The Distribution of School-Supporting Nonprofit Revenue}

\begin{tabular}{|c|c|c|c|c|c|c|}
\hline \multirow{3}{*}{$\begin{array}{l}\text { State revenues per } \\
\text { pupil (in } \$ 100)\end{array}$} & \multicolumn{3}{|c|}{ DV: Per-pupil voluntary contributions } & \multicolumn{3}{|c|}{$\begin{array}{l}\text { DV: Difference in per-pupil voluntary } \\
\text { contributions }\end{array}$} \\
\hline & $\begin{array}{c}\text { I } \\
\text { Reduced } \\
\text { Form } \\
\end{array}$ & $\begin{array}{c}\text { II } \\
\text { State FE }\end{array}$ & $\begin{array}{c}\text { III } \\
\text { District FE }\end{array}$ & $\begin{array}{c}\text { IV } \\
\text { Reduced } \\
\text { Form } \\
\end{array}$ & $\begin{array}{c}\mathrm{V} \\
\text { State FE }\end{array}$ & $\begin{array}{c}\text { VI } \\
\text { District FE }\end{array}$ \\
\hline & $\begin{array}{c}-0.319 * * * \\
(0.080)\end{array}$ & $\begin{array}{c}-0.267 * * \\
(0.088)\end{array}$ & $\begin{array}{l}-0.202^{*} \\
(0.095)\end{array}$ & $\begin{array}{l}- \\
-\end{array}$ & - & - \\
\hline $\begin{array}{l}\text { Difference in state } \\
\text { revenues per pupil }\end{array}$ & - & $\begin{array}{l}- \\
-\end{array}$ & $\begin{array}{l}- \\
-\end{array}$ & $\begin{array}{c}0.014 \\
(0.047)\end{array}$ & $\begin{array}{c}0.018 \\
(0.048)\end{array}$ & $\begin{array}{c}0.039 \\
(0.055)\end{array}$ \\
\hline $\begin{array}{l}\text { Per pupil expenditures } \\
\text { (ln) }\end{array}$ & $\begin{array}{c}0.001 \\
(0.001)\end{array}$ & $\begin{array}{c}0.002 \\
(0.001)\end{array}$ & $\begin{array}{c}0.001 \\
(0.001)\end{array}$ & - & $\begin{array}{l}- \\
-\end{array}$ & $\begin{array}{l}- \\
-\end{array}$ \\
\hline $\begin{array}{l}\text { Difference in per } \\
\text { pupil expenditures }\end{array}$ & - & - & $\begin{array}{l}- \\
-\end{array}$ & $\begin{array}{l}-0.000 \\
(0.000)\end{array}$ & $\begin{array}{l}-0.000 \\
(0.000)\end{array}$ & $\begin{array}{c}0.000 \\
(0.000)\end{array}$ \\
\hline Percent English & & & & & & \\
\hline Learners & $\begin{array}{c}64.594 \\
(33.663)\end{array}$ & $\begin{array}{c}37.046 \\
(47.113)\end{array}$ & $\begin{array}{c}3.673 \\
(15.192)\end{array}$ & $\begin{array}{c}4.617 \\
(4.306)\end{array}$ & $\begin{array}{c}6.288 \\
(5.377)\end{array}$ & $\begin{array}{l}21.970 * \\
(10.287)\end{array}$ \\
\hline Enrollment (ln) & $\begin{array}{l}-9.960 * * * \\
(2.498)\end{array}$ & $\begin{array}{l}-10.158^{* *} \\
(3.274)\end{array}$ & $\begin{array}{l}-61.708 \\
(42.552)\end{array}$ & $\begin{array}{l}-0.185 \\
(0.427)\end{array}$ & $\begin{array}{l}-0.290 \\
(0.518)\end{array}$ & $\begin{array}{l}-19.534 \\
(13.605)\end{array}$ \\
\hline Pupil-teacher ratio & $\begin{array}{c}0.793 \\
(0.888)\end{array}$ & $\begin{array}{l}-1.761^{*} \\
(0.850)\end{array}$ & $\begin{array}{l}0.721 * \\
(0.353)\end{array}$ & $\begin{array}{l}-0.082 \\
(0.081)\end{array}$ & $\begin{array}{l}-0.030 \\
(0.239)\end{array}$ & $\begin{array}{c}0.432 \\
(0.393)\end{array}$ \\
\hline $\begin{array}{l}\text { Percent free/reduced } \\
\text { lunch }\end{array}$ & $\begin{array}{l}-23.452 \\
(13.201)\end{array}$ & $\begin{array}{l}-39.434 * * \\
(14.624)\end{array}$ & $\begin{array}{l}-37.212 * * * \\
(11.037)\end{array}$ & $\begin{array}{l}-3.003^{*} \\
(1.462)\end{array}$ & $\begin{array}{c}-3.265^{* *} \\
(1.100)\end{array}$ & $\begin{array}{c}-8.608 \\
(12.910)\end{array}$ \\
\hline 2000 & $\begin{array}{c}1.206 \\
(1.180)\end{array}$ & $\begin{array}{c}0.880 \\
(1.473)\end{array}$ & $\begin{array}{c}3.419 * * * \\
(0.927)\end{array}$ & $\begin{array}{l}-0.538 \\
(0.943)\end{array}$ & $\begin{array}{l}-0.540 \\
(0.972)\end{array}$ & $\begin{array}{c}0.048 \\
(1.030)\end{array}$ \\
\hline 2001 & $\begin{array}{c}1.412 \\
(1.434)\end{array}$ & $\begin{array}{c}0.147 \\
(1.985)\end{array}$ & $\begin{array}{c}5.791 * * * \\
(1.354)\end{array}$ & $\begin{array}{l}-0.736 \\
(1.004)\end{array}$ & $\begin{array}{l}-0.668 \\
(1.025)\end{array}$ & $\begin{array}{c}0.439 \\
(1.079)\end{array}$ \\
\hline 2002 & $\begin{array}{c}3.182 \\
(2.294)\end{array}$ & $\begin{array}{c}1.394 \\
(2.325)\end{array}$ & $\begin{array}{c}9.808 * * * \\
(1.961)\end{array}$ & $\begin{array}{l}-0.927 \\
(1.199)\end{array}$ & $\begin{array}{l}-0.911 \\
(1.223)\end{array}$ & $\begin{array}{c}0.268 \\
(1.350)\end{array}$ \\
\hline 2003 & $\begin{array}{l}3.730 \\
(2.004)\end{array}$ & $\begin{array}{l}1.889 \\
(2.242)\end{array}$ & $\begin{array}{c}12.371 * * * \\
(2.417)\end{array}$ & $\begin{array}{l}-0.270 \\
(0.922)\end{array}$ & $\begin{array}{l}-0.437 \\
(0.864)\end{array}$ & $\begin{array}{c}0.905 \\
(1.200)\end{array}$ \\
\hline 2004 & $\begin{array}{l}5.825^{*} \\
(2.496)\end{array}$ & $\begin{array}{c}2.659 \\
(2.335)\end{array}$ & $\begin{array}{c}15.279 * * * \\
(2.771)\end{array}$ & $\begin{array}{l}-0.366 \\
(0.914)\end{array}$ & $\begin{array}{l}-0.830 \\
(0.971)\end{array}$ & $\begin{array}{c}1.255 \\
(1.538)\end{array}$ \\
\hline 2005 & $\begin{array}{l}8.546^{* *} \\
(2.463)\end{array}$ & $\begin{array}{c}3.485 \\
(2.689)\end{array}$ & $\begin{array}{c}18.859 * * * \\
(3.164)\end{array}$ & $\begin{array}{c}0.335 \\
(0.940)\end{array}$ & $\begin{array}{l}-0.226 \\
(0.973)\end{array}$ & $\begin{array}{c}2.083 \\
(1.657)\end{array}$ \\
\hline 2006 & $\begin{array}{c}11.871 * * * \\
(3.069)\end{array}$ & $\begin{array}{c}6.664 \\
(3.498)\end{array}$ & $\begin{array}{c}23.756^{* * *} \\
(3.681)\end{array}$ & $\begin{array}{c}0.816 \\
(0.831)\end{array}$ & $\begin{array}{c}0.443 \\
(0.888)\end{array}$ & $\begin{array}{c}2.956 \\
(1.904)\end{array}$ \\
\hline 2007 & $\begin{array}{c}13.101 * * \\
(3.796)\end{array}$ & $\begin{array}{l}8.646^{*} \\
(3.869)\end{array}$ & $\begin{array}{c}28.442 * * * \\
(4.763)\end{array}$ & $\begin{array}{c}2.047 \\
(1.083)\end{array}$ & $\begin{array}{c}2.049 \\
(1.069)\end{array}$ & $\begin{array}{c}4.363 \\
(2.486)\end{array}$ \\
\hline 2008 & $\begin{array}{c}17.528 * * \\
(6.462)\end{array}$ & $\begin{array}{l}11.528 \\
(7.322)\end{array}$ & $\begin{array}{c}29.604 * * * \\
(4.840)\end{array}$ & $\begin{array}{l}-1.014 \\
(1.370)\end{array}$ & $\begin{array}{l}-0.904 \\
(1.373)\end{array}$ & $\begin{array}{l}1.636 \\
(2.352)\end{array}$ \\
\hline 2009 & $\begin{array}{c}16.386^{*} \\
(6.586)\end{array}$ & $\begin{array}{c}8.787 \\
(7.706)\end{array}$ & $\begin{array}{c}27.849 * * * \\
(4.594)\end{array}$ & $\begin{array}{c}-5.698 * * * \\
(1.200)\end{array}$ & $\begin{array}{c}-5.747 * * * \\
(1.235)\end{array}$ & $\begin{array}{l}-3.064 \\
(2.240)\end{array}$ \\
\hline Constant & $\begin{array}{c}105.027 * * \\
(30.758) \\
\end{array}$ & $\begin{array}{c}144.289 * * * \\
(29.686) \\
\end{array}$ & $\begin{array}{c}560.665 \\
(373.675) \\
\end{array}$ & $\begin{array}{c}5.950 \\
(4.154) \\
\end{array}$ & $\begin{array}{c}5.872 \\
(6.394) \\
\end{array}$ & $\begin{array}{c}169.287 \\
(119.318) \\
\end{array}$ \\
\hline Observations & 16,872 & 16,872 & 16,872 & 15,921 & 15,921 & 15,921 \\
\hline $\mathrm{R}^{\wedge} 2$ & 0.025 & 0.052 & 0.051 & 0.004 & 0.007 & 0.006 \\
\hline adj. $R^{\wedge} 2$ & 0.024 & 0.049 & 0.050 & 0.003 & 0.003 & 0.005 \\
\hline
\end{tabular}

$* \mathrm{p}<.1 ; * * \mathrm{p}<.05 ; * * * \mathrm{p}<.01$ 